The ratio of widths is about five to three, with about the ratio of five to four in depth; the latter, however, being a very rough approximation. At old Fort Selkirk nothing but the chimneys, three in number, are left standing: the fate of this post has been alluded to in an earlier part of the article.

The latitude of Fort Selkirk is $62^{\circ} 45^{\prime} 46^{\prime \prime}$ north, and its longitude $137^{\circ} 22^{\prime} 45^{\prime \prime}$ west (Greenwich). Altogether on the Yukon River, this far, there had been taken thirty-four astronomical observations, four hundred and twenty-five with the prismatic compass, and two for variation of compass. I hope they have been sufficiently accurate; at least, to subserve all practical purposes of exploration in this country, until more exact surveys are demanded by the opening of some industry or commerce, should that time ever come. No meteorological observations were taken, the party not being furnished with instruments, and the rapid passage through a vast tract of country making their usefulness to science highly problematical. The nearest point to the upper Yukon, at which regular observations of this character are recorded, is the Chilcat salmon-cannery of the North-west trading company on Chilcat Inlet. The two are separated by the Kotusk Mountains, making meteorological inferences, therefore, very unreliable. Nearly a hundred botanical specimens were collected on the upper Yukon, and have been placed in the able hands of Mr. Watson, curator of the Harvard herbarium, for analysis. While only a limited and crude amateur's collection, it may throw some little light on the general character of the flora, as limited to the river-bed, which we seldom left in our more important duties connected with the main object of the reconnoissance.

The map is necessarily condensed for so large an area ; and having been made hurriedly, and expressly for this article, it is not wrought so much for topographical effect as exactness within the limits possible under such circumstances. The map which will accompany my official report is on a much larger scale, and much better prepared in details. To Mr. Homan, my topographical assistant, is due all the credit relating to the map-making department, except simply the astronomical observations, and in those requiring an assistant, when he acted as recorder. The above account has mostly been taken in chronological sequence from my daily journal, and matters of the same character have thus been separated in different parts of the article. If, with all these defects, I have made clear my small addition to geographical research to the readers of $\mathrm{Sci}$ ence, I shall feel deeply repaid for the great labor I had in securing it.

In my geographical nomenclature I have tried to observe the following rules. Wherever a descriptive name would assist any future traveller in identifying the object, I have applied it, to the exclusion of all others, Indian or civilized ; as, Red Butte, Bald Hill, Cone-Hill River, Haystack Island, etc. Where Indian names are simple, $I$ have tried to retain them, as Kotusk, Tahk-o, Tahk-heen-a, Kluk-tas-si, Dayay, etc. In all other cases, where the object was deserving of being named, I have not hesitated to attach the names of men worthy of such distinction, both personal friends in all branches of science, and those who have done something for geographical research, and without regard to country. In my larger map I have also added the native names, where they could be secured.

The total length of part first, the part explored and surveyed by this reconnoissance, was 538.8 miles; the total length of the raftjourney on part first, from camp on Lake Lindeman to Fort Selkirk, 486.8 miles; the total length of the raft-journey on Yukon River, from Lake Lindeman to Nuklakayet (being the longest raft-journey in the interest of geographical science), 1,303.2 miles; the length of Yukon River, 2,043.5 miles.

$$
\begin{aligned}
& \text { Fred'k Schwatka, } \\
& \text { Lieut. U.S. Army. }
\end{aligned}
$$

\section{NOTE ON THE FLORA OF THE UPPER YUKON.}

Lieut. Schwatka was able to make a small botanical collection from about the head waters of the Yukon, which is of considerable interest as an indication of the climate of the region, and as showing the range northward into the $\mathrm{Yu}$ kon valley, of some species previously known scarcely beyond the British boundary. Lieut. Schwatka, ascending from the head of Chilcoot Inlet, crossed the main coast-range by the Perrier Pass at an altitude of 4,100 feet, coming at once upon the source of the Yukon River, in latitude $59^{\circ} 40^{\prime}$. A descent of twelve miles brought him to Lake Lindeman; and upon the borders of this and other lakes within a distance of twenty-five miles, nearly equally on both sides of the sixtieth parallel, the larger part of the collection was made, between the 12 th and 15 th of June. The specimens gathered even at this date were in full bloom, excepting a few indicated in the following list 
by parentheses, and the sedges and grasses, which were well developed.

Anemone parviflora. Aquilegia formosa. Aconitum Napellus, var.

Barbarea vulgaris.

Arabis petraea.

Cardamine hirsuta, var.

Viola cucullata.

Lupinus arcticus.

Rubus Chamaemorus.

(Poterium Sitchense?)

Saxifraga tricuspidata.

Saxifraga leucanthemifolia.

Parnassia fimbriata.

Ribes rubrum.

Epilobium spicatum.

Epilobium latifolium.

(Heracleum lanatum.)

Cornus Canadensis.

Antennaria alpina.

Arnica latifolia.

(Senecio triangularis.)

Vaccinium parvifolium.

Arctostaphylos Uva-ursi.

Bryanthus empetriformis.

Kalmia glauca.

Ledum latifolium.

(Moneses uniflora.)

Pyrola secunda.

Dodecatheon Meadia, var.

Polemonium humile.

Mertensia paniculata.

Polygonum viviparum.

(Betula glandulosa.)

(Alnus viridis.)

Salix glauca.

Salix Sitchensis.

Habenaria dilatata.

Streptopus roseus.

Carex (2 sp.).

Deyeuxia Langsdorffii.

Festuca ovina

Lycopodium complanatum.

Lycopodium annotinum.

The rest of the collection was made as opportunity offered, during the descent to Fort Selkirk in latitude $62^{\circ} 45^{\prime}$, which point was reached on the 13th of July. It included the following species :-

Anemone multifida.

Galium boreale.

Ranunculus Flammula, var.

Erysimum parviflorum.

Cerastium arvense.

Arenaria lateriflora.

Arenaria phy'sodes.

Montia fontana.

Linum perenne.

Hedysarum boreale.

Rubus arcticus.

Fragaria vesca (?)

Potentilla fruticosa.

Amelanchier alnifolia.

Parnassia palustris.

Bupleurum ranunculoides.

Aster Sibiricus.

Achillea millefolium.

Artemisia vulgaris.

Arnica alpina.

Arnica Chamissonis.

Pyrola rotundifolia, var.

Primula Sibirica.

Myosotis sylvatica, var.

Pentstemon confertus.

Pentstemon glaucus (?).

Pedicularis flammea.

Chenopodium album.

Polygonum aviculare.

Zygadenus elegans.

Hordeum jubatum.

The species new to so northern a latitude are marked by italics. The season appears to have been as forward as I found it in 1868 in the lower mountain ranges rising from the plateau of western Nevada in latitude $40^{\circ}$.

Sereno Watson.

\section{THE INTELLIGENCE OF SNAKES.}

Nerther among the scanty early references to the serpents found in New Jersey, nor in more recent herpetological literature, are there to be found statements that bear directly upon the subject of the intelligence of snakes. Gabriel Thomas, writing of West New Jersey as long ago as 1698 , quite ignores the fourteen species with which we are favored. Thomas Campanius, in his history of New Sweden, published in 1702, and which is based on the notes made by his grandfather during his brief stay in Pennsylvania sixty years before, also ignores our harmless snakes, but remarks of the rattlesnake (Crotalus horridus), "It has a head like a dog, and can bite off a man's leg as clear as if it had been hewn down with an axe." What may we not expect, when such statements as this are made by men of intelligence? Assertions equally absurd are not uncommonly made, even in these later days, when a correct knowledge of our common animals is supposed to prevail.

Nearly half a century later than the date of publication of Campanius' history, Peter Kalm, the Swedish naturalist, travelled in New Jersey, and spent much time, particularly in the southern counties of the state. In his entertaining volumes, he has made many references to our snakes, although not enumerating all of them, and mentioning some that certainly do not now exist. This author relates several wonderful stories of the fierceness of the black snake, as they were told to him, and likewise gives his personal experience with this same serpent, which, to his surprise, did not accord with what he had heard. The reason is plain enough. Kalm desired to know the truth, and took the experimental way of learning it. His knowledge of the snakes was gained by familiar out-of-doors intercourse with them, and it has stood the test of time. All that was needed, when he wrote, was the moral courage to say to the narrators of the marvellous stories, 'You are mistaken ;' or perhaps, more wisely, he might have kept silent. 'The most conscientious man, if afraid of snakes, cannot tell the truth about them; and even in the case of the truly poisonous species, it is well to remember that 'the devil is not so black as he is painted.' Stress has been laid upon the exaggerated statements of authors when treating of snakes, for the reason, that, if there were any foundation for the marvellous stories narrated, it would prove conclusively that the serpent was indeed wise. But setting aside all the literature of the subject, and going directly to the woods and fields, what evidence do we find there of the intelligence of snakes?

On the farm of the writer there have been found eleven species of snakes, which is but four less than the whole number found in New Jersey. Of these eleven species, no one is venomous ; and, it may be added, all are perfectly harmless, and, indeed, cowardly. It is true that when cornered they will show fight, 